\title{
Lead-alpha age determinations of granitic rocks from Alaska
} By J. J. Matzko, H. W. Jaffe, and C. L. Waring

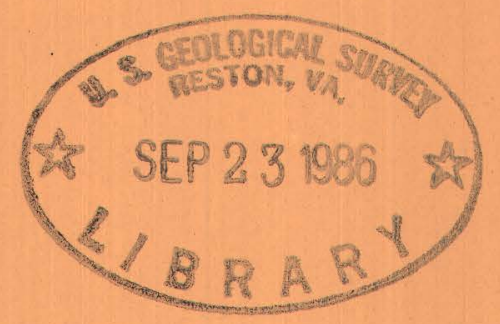

\section{Trace Elements Investigations Report 618}

UNITED STATES DEPARTMENT OF THE INTERIOR GEOLOGICAL SURVEY

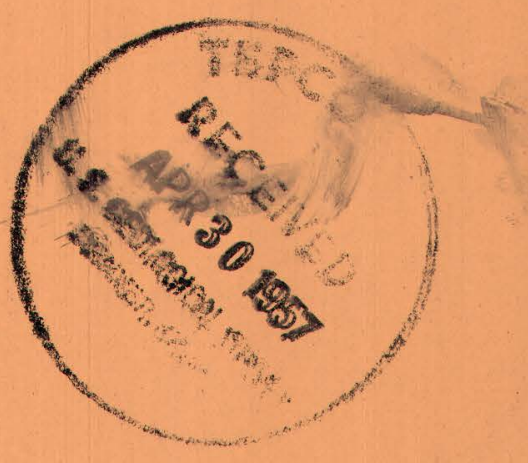


Geology and Mineralogy

UNITED STATES DEPARTMENT OF THE INTERIOR

GEOLOGICAL SURVEY

LFAD-ALPHA AGE DETERMINATIONS OF GRANITIC ROCKS

FROM ALASKLA*

By

J. J. Matzko, H. W. Jaffe, and C. L. Waring

March 1957

Trace Flements Investigations Report 618

This preliminary report is distributed without editorial and technical review for conformity with official standards and nomenclature. It is not for public inspection or quotation.

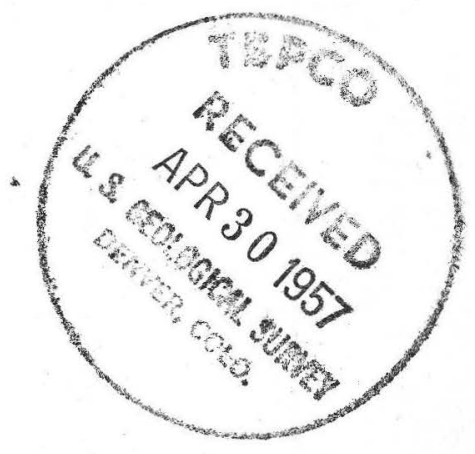

* This report concerns work done on behalf of the Division

of Raw Materials of the U. S. Atomic Energy Commission. 
USGS - TEI-618

GEOLOGY AND MINERALOGY

Distribution

No. of copies

Atomic Energy Commission, Washington. . . . . . . . . 2

Division of Raw Materials, Albuquerque. . . . . . . . . I

Division of Raw Materials, Austin . . . . . . . . . . I

Division of Raw Materials, Casper ........... 1

Division of Raw Materials, Denver ............ 1

Division of Raw Materials, Ishpeming. . . . . . . ... I

Division of Raw Materials, Phoenix............ I

Division of Raw Materials, Rapid City ........... I

Division of Raw Materials, Salt Lake City . . . . . . . I I

Division of Raw Materials, Spokane............. I

Division of Raw Materials, Washington .......... 3

Exploration Division, Grand Junction Operations Office...... I

Grand Junction Operations Office............. 1

Technical Information Service Extension, Oak Ridge. . . . . 6

Terr. Department of Mines, Anchorage (Martin Jasper). . . . . . I

Terr. Department of Mines, College (R. H. Saunders) ...... I

Terr. Department of Mines, Juneau (P. H. Holdsworth). . . . . I I

Terr. Department of Mines, Ketchikan (A. E. Glover) ...... I

Terr. Department of Mines, Nome (P. O. Sandvik) ........ 1

U. S. Geological Survey:

Alaskan Geology Branch, Menlo Park. . . . . . . . . 5

Fuels Branch, Washington. ............. 1

Geochemistry and Petrology Branch, Washington ........ 1

Geophysies Branch, Washington ............. I

Mineral Deposits Branch, Washington ............ I

A. I. Brokaw, Grand Junction ............. 1

V. L. Freeman, College................ 1

I. R. Page, Washington. ............. I

I. H. Saarela, Anchorage. . . . . . . . ... 1

R. S. Velikanje, Juneau ............... 1

A. E. Weissenborn, Spokane.............. I

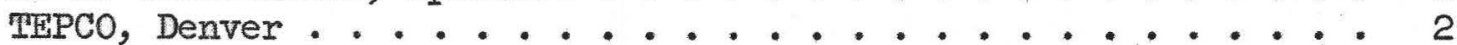

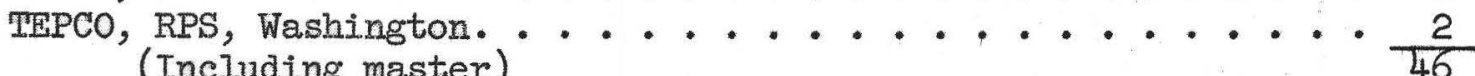


CONIENIS

•...................... 5

Introduction. .......................... . 5

Southeastern and east-central Alaska. . . . . . . . . . . 8

Mt. Fairplay ..................... 8

Geology ..................... . 8

Age determination................ 10

Tolstoi Point. . . . . . . . . . . . . . . . . 11

Geology ................... 11

Age determination ............... 15

Turner Lake. . . . . . . . . . . . . . . . . 15

Geology ......................... 15

Age determination .............. 17

Central Alaska. . . . . . . . . . . . . . . . . 17

Birch Creek. . . . . . . . . . . . . . . . 17

Geology ................... . 17

Age determination ................ 19

Flat Creek and Chicken Creek . . . . . . . . . . . . 19

Geology ................... . 19

Age determination ................ 21

Nixon Fork mines . . . . . . . . . . . . . . . 22

Geology .................... 22

Age determination .............. 24

Surmary . . . . . . . . . . . . . . . . . . 24

References cited. . . . . . . . . . . . . . . 26

Unpublished reports . . . . . . . . . . . . . . . . 27

\section{IILUSTRATIONS}

Figure 1. Quadrangle index map of a portion of Alaska showing

Page samplie loeations............... 6

2. Sketch map showing location of sample from Mt. Fairplay area, Tanacross quadrangle, Alaska . . . . . 9

3. Sketch map showing sample locations from Tolstoi

Point, Craig quadrangle, Alaska . . . . . . . . 12

4. Sketch map showing location of sample from Turner

Lake, Taku River quadrangle, Alaska... . . . . 16

5. Sketch map showing location of sample from Birch Creek,

Ruby quadrangle, Alaska................. 18

6. Sketch map showing locations of samples from Flat Creek and Chicken Creek, Iditarod quadrangle, Alaska . . . . 20 
Page

Figure 7. Sketch map showing location of sample from Nixon Fork mines, Medfra quadrangle, Alaska. . . . . . . . .

\section{TABLE}

Table 1. Summary of lead-alpha age determinations of igneous rocks from Alaska. . . . . . . . . . . . . 25 
IEAD-ALPHA ACE DETERMINATIONS OF GRANITIC ROCKS FROM ALASKA

By J. J. Matzko, H. W. Jaffe, and C. I. Waring

\section{ABSTRACT}

Lead-slpha activity age determinations were made on zircon from seven granitic rocks of central and southeastern Alaska. The results of the age determinations indicate two periods of igneous intrusion, one about 95 million years ago, during the Cretaceous period, and another about 53 million years ago, during the early part of the Tertiary. The individual ages determined on zircon from 2 rocks from southeastem Alaska and I from east-central Alaska gave results of 90 , 100, and 96 million years; those determined on 4 rocks from central Alaska gave results of $47,56,58$, and 51 million years.

\section{INIRODUCPION}

Most of Alaska has been mapped on a reconnaissance basis and definite age correlations are lacking in many areas. The igneous areas mapped in greater detail also may be of indefinite age because of the absence of diagnostic fossils in nearby sedimentary rocks and the inability, owing to lack of exposures, to correlate lithologically with rocks of known age. As a means of obtaining the age or corroboratingthe ages of the igneous rocks estimated from the geology, it was decided to determine the lead-alpha ages of the zircons concentrated from igneous rocks collected from several localities in Alaska (fig. 1).

Samples of granites from which the age determinations were made were collected by White, Nelson, and Matzko (1956) from Mount Fairplay in the Tanacross quadrangle (fig. 2), by Sainsbury (in 
preparation) from Tolstoi Point in southeastern Alaska (fig. 3), by Plafker (in preparation) from Tumer Lake, Taku Inlet in southeastern Alaska (fig. 4), by White and Stevens (1953) from Birch Creek in the Ruby-Poorman district of central Alasika (fig. 5), by White and Killeen (1953) from Flat Creek and Chicken Creek, in the Iditarod quadrangle (fig. 6), and by Matzko and Bates (in preparation) from the Nixon Fork mines area, Medfra quadrangle (fig. 7). The work was done by the Geological Survey on behalf of the Division of Raw Materials, U. S. Atomic Energy Commission.

These are the first age determinations of minerals from Alaskan igneous rociss. Although additional work is planaed, this preliminary study indicates two periods of igneous intrusion in southeastern and central Alaska, one about 95 million years ago during the Cretaceous period and another about 53 million years ago during the early part of the Tertiary period. Ages determined on zircon from 6 of the 7 rocks are in good agreement with the geologic estimates of their age; the age of the other is in disagreement with the geologic estimate of age. Separation and purification of zircons for age determinations and alpha counts were made by J. J. Matzko and H. W. Jaffe. All lead determinations were made spectrographically by C. L. Waring. The method used in the determination of the ages of the zircons has been described in other reports by Larsen, Keevil and Harrison (1952), Gottfried, Senftle, and Jaffe (1955), and by Jaffe, Gottfried, and Waring (1955). 
SOUTHEASTERN AND EAST-CENIRAL ALASKA

Mt. Fairplay

Geology

White, Nelson, and Matzko (in preparation) in theix reconnaissance investigation for uranium in the Fortymile district, collected samples in the Tanacross quadrangle from near Mt. Fairplay (fig. 2). Granitic rocks were intruded in many parts of Alasks some time in the Late Jurassic or Early Cretaceous epochs and Mertie (1937) suggested that the granitic rocks of the Fortymile district may have been formed at about the same time.

The large body of granitic rock at Mt. Fairplay and many smaller bodies nearby were mapped as Mesozoic in age by Mertie (1937, p. 215-216, and pl. 1). He acknowledges, however, that on the basis of stratigraphic evidence alone these granitic rocks can be mapped only as post-Paleozoic and pre-Tertiary. The sample collected for age determination, no. 3881 , from the western slope of Mt. Falrplay proved to be a leucosyenite composed essentially of microperthite and subordinate albite-oligoclase. A point-count modal analysis of a thin section of the rock gave:

\begin{tabular}{lr} 
Perthite & 59.2 \\
Albite-oligoclase & 35.8 \\
Quartz & 0.4 \\
Others* & 4.6 \\
\hline & 100.0
\end{tabular}

*predominantly hornblende, biotite, sphene, opaques, and zircon in order of decreasing abundance.

The rock had an average grain diameter of $2 \mathrm{~mm}$. 


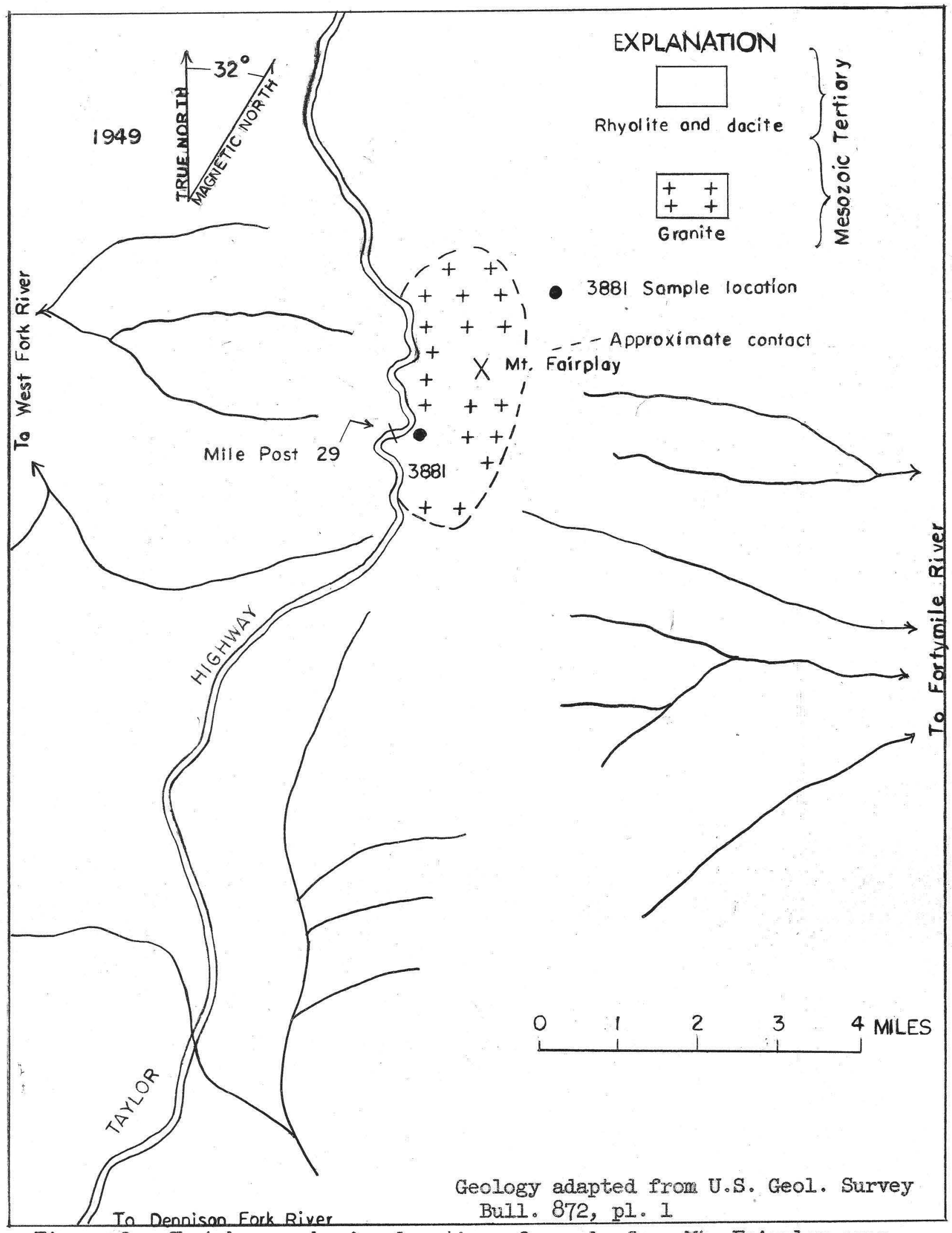

Figure 2.--Sketch map showing location of sample from Mt. Fairplay area, Tanacross quadrangle, Ala ska 
Age determination

Three fractions of zircon, differing in magnetic response, were obtained by passing the concentrate through the Frantz magnetic separator at varying amperage and tilt. The zircon concentrates consisted of whole and broken erystals with a squat habit, showing short prisms doubly terminated by the pyramids. Some of the crystals were almost equant in the absence of the more characteristic elongation of the prisms. The zircons ranged in color from a pale buff in the least magnetic fraction to brown in the most magnetic fraction. Microscopic examination of the three fractions of zircon indicated that the brown was due essentially to an unidentified brown material coating many of the zircon grains to a varying degree, and to the more metamict state of some of the grains. Most of the zircon grains were zoned, consisting essentially of fresh zircon with an omega index of refraction of 1.92 and optically continuous narrow zones of metamict zircon for which the omega index of refraction ranged from 1.86 to 1.90 . Some of the grains also contained some unidentified microscopic inclusions. The more magnetic fractions contained more of the metamict zones of zircon and showed a systematic increase in the lead content and alpha activity. Splits of the three fractions of zircon, 3881B, 3881C, and 3881E were then leached in a 1-1 nitric acid for a period of 15 minutes, resulting in solution of the brown material coating most of the zircon grains with an accompanying loss of both lead and alpha activity. Splits of samples $3881 \mathrm{C}$ and 3881 were also leached in concentrated nitric acid with similar results. Lead-alpha age determinations made of the three fractions of zircon before and after nitric acid treatment gave the following results: 


\begin{tabular}{cccc} 
Sample & $\alpha / \mathrm{mg} / \mathrm{hr}$ & $\mathrm{Pb}(\mathrm{ppm})$ & Age (M.Y.) \\
\hline $3881-B$ (untreated) & 1620 & 68 & 101 \\
(1-1 nitric acid) & 1134 & 45 & 95 \\
$3881-C$ (untreated) & 1930 & 72 & 90 \\
(1-1 nitric acid) & 1476 & 63 & 102 \\
(concentrated nitric & 1270 & 48,52 & 94 \\
acid) & 2600 & 115 & 106 \\
3881-E (untreated) & 1594 & 72 & 108 \\
(1-1 nitric acid) & 1550 & 60,63 & 96 \\
(concentrated nitric & & & 99 \\
acid) & &
\end{tabular}

Although a considerable amount of the alpha activity and lead was removed from each sample by the acid treatment, the ages remain in good agreement, suggesting a solution of thorite (isostructural with zircon) or metamict zones of zircon, rather than selective removal of uranium, thorium, or lead. The average of the eight age determinations, 99 milIion years, corresponds to the Cretaceous period for which a range of 60-130 million years was established by the Committee on the Measurement of Geologic Time for 1949-50 (Marble, 1950).

Tolstoi Point

Geology

Sainsbury, in 1955 (in preparation) as part of his study of Prince of Wales Island and vicinity, collected samples of the quartz diorite from Tolstoi Point, Prince of Wales Island, Craig C-2 quadrangle (fig. 3 ). The intrusive at Tolstoi Point has been described by Warner and Goddard (in preparation) as elongate, stock-like masses of diorite. Porphyry dikes are cut by the stock and alkali andesite dikes intrude the stock. The Tolstoi Mountain stock is composed mainly of light-gray 


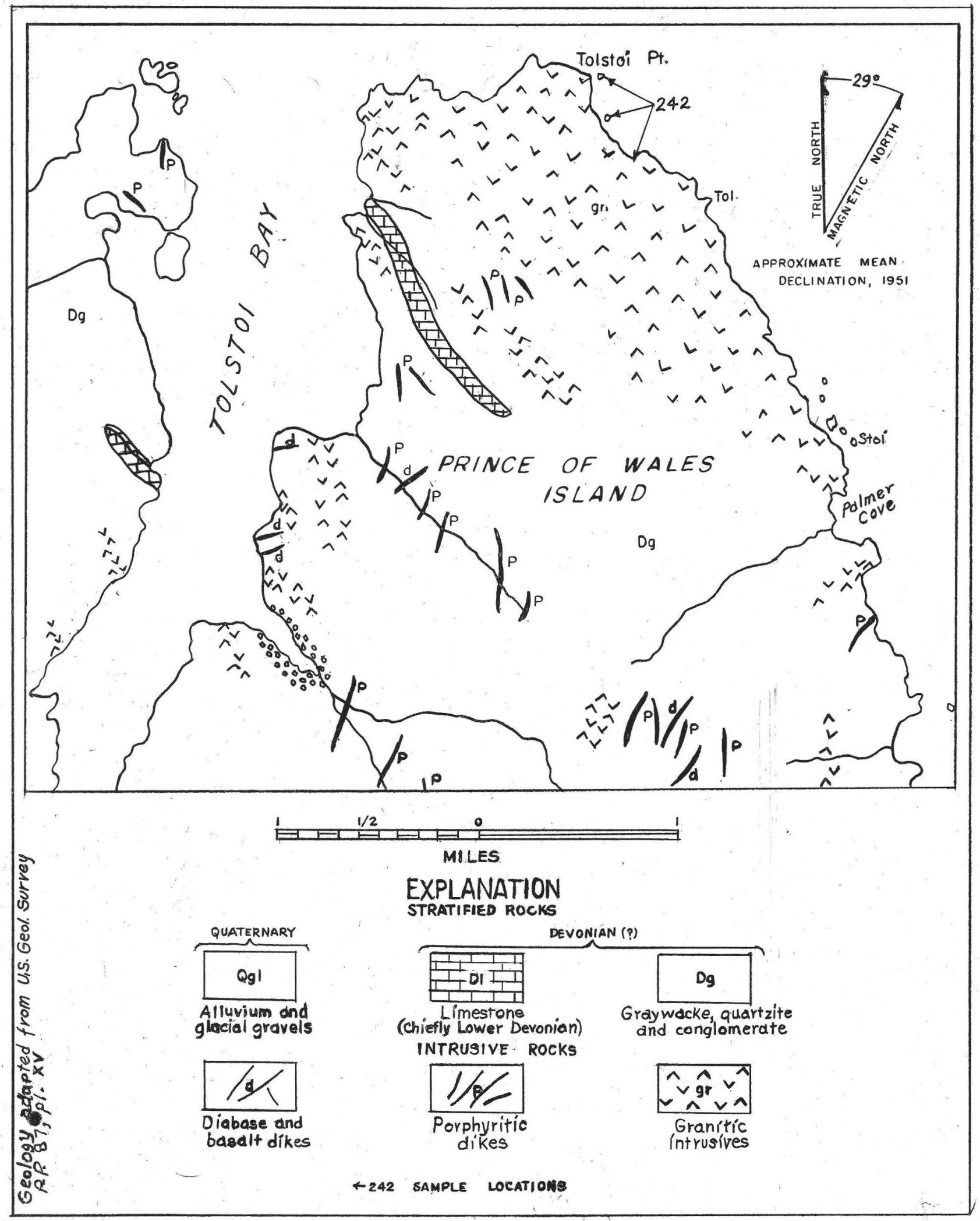

Figure 3.--Sketch map showing sample locations from Tolstoi Point, Craig quadrangle, Alaska 
quartz-bearing diorite with medium-grained to coarse-grained granitoid texture. Wright (1915) has noted. that the stock iavades sedimentary strata of Devonian age. Buddington and Chapin (1929) suggest that the igneous rocks of Prince of Wales Island are satellitic intmusions of the Coast Range batholith which forms most of the mainland of southeastern Alaska. The age of the batholith is believed to be Late Jurassic or Early Cretaceous.

A calculation of the norm, according to the C.I.P.W. classification, and the chemical analysis from which the norm was derived is shown below for Sainsbury's sample no. 242. In the classification the rock falls into class 2, order 4, rang 3 and subrang 3. The chemical analysis by : rapid rock analysis methods was made by P.L.D. Elmore, K. E. White, and S. D. Botts, of the U. S. Geological Survey.

\begin{tabular}{|c|c|c|c|}
\hline No. 242 & $\begin{array}{l}\text { Weight } \\
\text { Percent }\end{array}$ & & $\begin{array}{c}\text { Norm } \\
\text { Percent }\end{array}$ \\
\hline $\mathrm{SiO}_{2}$ & 52.8 & Quartz & 3.6 \\
\hline $\mathrm{Al}_{2} \mathrm{O}_{3}$ & 15.9 & Albite & 26.2 \\
\hline $\mathrm{Fe}_{2} \mathrm{O}_{3}$ & 2.4 & Anorthite & 26.7 \\
\hline $\mathrm{FeO}$ & 7.5 & Orthoclase & 6.1 \\
\hline $\mathrm{MgO}$ & 5.5 & Hypersthene & 18.3 \\
\hline $\mathrm{CaO}$ & 8.9 & Diopside & 11.3 \\
\hline $\mathrm{Na}_{2} \mathrm{O}$ & 3.1 & Magnetite & 3.5 \\
\hline $\mathrm{K}_{2} \mathrm{O}$ & 1.0 & Ilmenite & 1.8 \\
\hline $\mathrm{TiO}_{2}$ & .98 & Apatite & 1.0 \\
\hline $\mathrm{P}_{2} \mathrm{O}_{5}$ & .44 & Calcite & .2 \\
\hline $\mathrm{MnO}$ & .21 & & \\
\hline $\mathrm{H}_{2} \mathrm{O}$ & 1.4 & & \\
\hline $\mathrm{CO}_{2}$ & .10 & & - \\
\hline & 100.2 & & 98.7 \\
\hline
\end{tabular}


A point-count modal analysis of the above rock shows the following:

\begin{tabular}{lc} 
& Percent \\
Plagioclase (andesine) & 50.6 \\
Quartz & 6.8 \\
Hornblende, green & 32.4 \\
Biotite-chlorite & 7.4 \\
Others & 2.8 \\
\hline
\end{tabular}

"Others" include opaques (magnetite and hematite), prehnite, zircon, sphene, apatite, clinozolsite, and pyroxene in decreasing order of abundance.

The rock is a quartz diorite. It has hypidiomorphic granular texture with an average grain size of $1.5 \mathrm{~mm}$. The plagioclase is generally subhedral; tabular-like grains may be euhedral with a maximum length of about $2 \mathrm{~mm}$; some grains show abundant alteration to sericite and other grains appear relatively fresh. The alteration is believed due primarily to deuteric alteration and not to surface weathering. Quartz is predominantly interstitial. Most grains show undulatory extinction and secondary overgrowth. Schiller structure is shown on a few of the green hornblende grains. The hornblende is altered in part to biotite and to chlorite. Prehnite has developed in the biotite along cleavage lines which it tends to distort. Quartz in minor amounts, also is found poikilitically in the biotite. The biotite shows some cataclastic effect with warped cleavage traces and a few of the grains showing drag effect on the biotite edges in contact with Presh plagioclase. Opaques are abundant in the hornblende and biotite and appear in part to cut off or replace sphene. A grain of euhedral zircon in the chlorite showed a strong pleochroic halo. 
Age determination

Age was determined on fresh, clear, doubly terminated zircon with no zoning and an index of refraction for omega of 1.92 .

$\begin{array}{cccc}\text { Sample no. } & \alpha / \mathrm{mg} / \mathrm{hr} & \mathrm{Pb}(\mathrm{ppm}) & \text { Age (M.Y.) } \\ 242 & 142 & 5.8,6.0 & 100\end{array}$

\section{Turner Lake}

\section{Geology}

In 1954 Plafker (in preparation), during his study of dam sites in southeastern Alaska, collected for age determination a sample from the Coast Range batholith at Turner Lake, Taku Inlet, Taku River quadrangle (fig. 4). An indefinite age of Late Jurassic or Early Cretaceous has been assigned to the Coast Range batholith in southeastern Alaska by Buddington and Chapin (1929, p. 253).

Plafker (in preparation), describes sample 106, (fig. 4) from which the zircon was concentrated, as a mediummgrained Iight-gray, hornblendebiotite granodiorite with a hypidiomorphic granular texture. A point-count modal analysis made by Plafker on the sample is shown below:

\begin{tabular}{lc} 
& Percent \\
\cline { 2 - 2 } Plagioclase (An 30-35) & 52.3 \\
Quartz & 21.2 \\
Biotite & 15 \\
Hornblende & 5 \\
Potassic feldspar & 6.4 \\
Others & .1 \\
$\quad$ Total & 100.0
\end{tabular}

"Others" are epidote and sphene that occur in trace amounts. The plagioclase is partly altered to sericite; biotite and hormblende are 


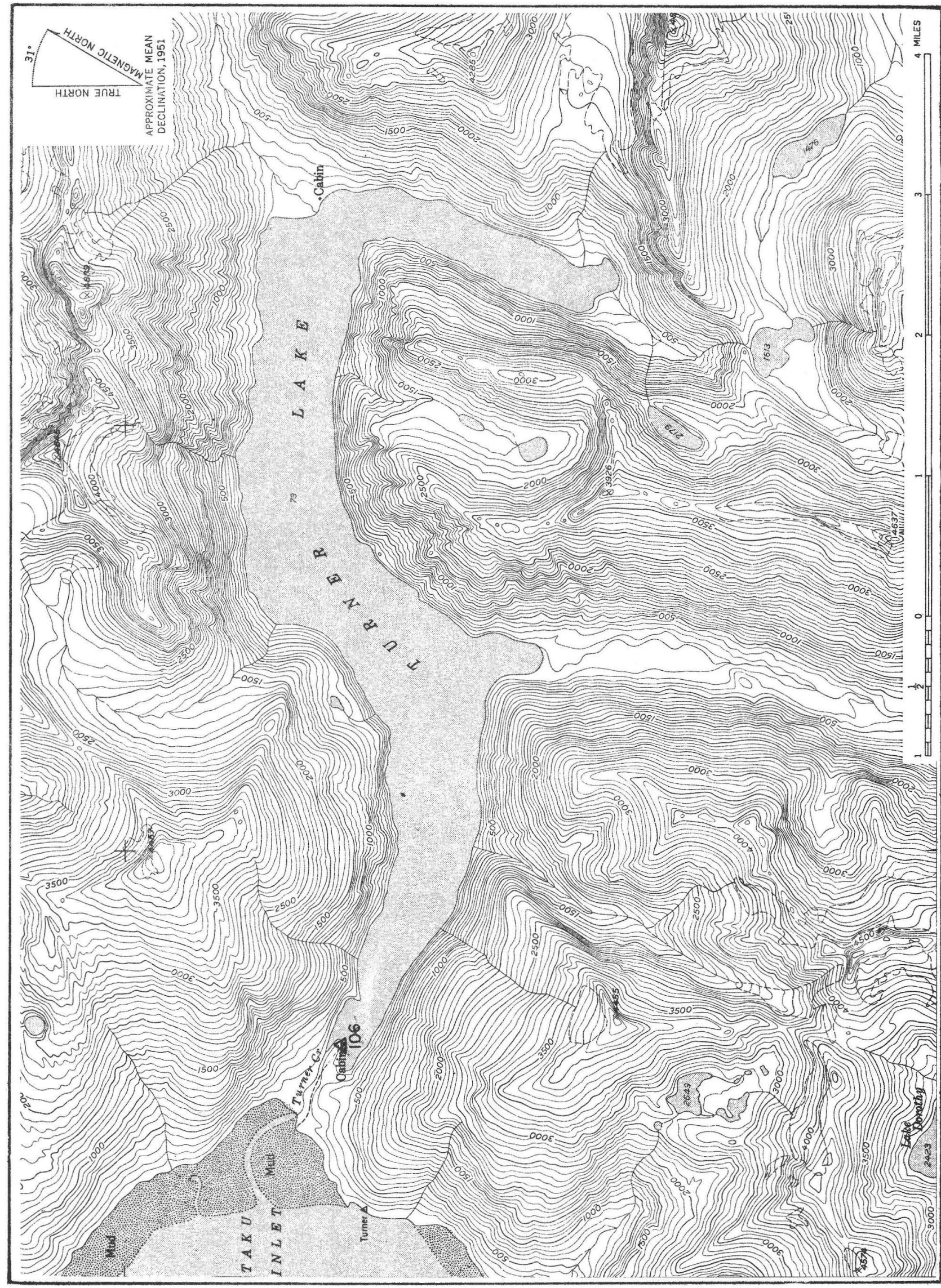

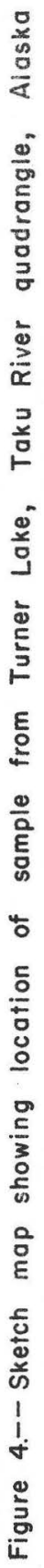


altered to chlorite. The average grain size of the granodiorite is $3.2 \mathrm{~mm}$.

Age determination

Age was determined on fresh, colorless, doubly-terminated, unzoned zircon with an omega index of refraction of 1.92 .

$\begin{array}{cccc}\text { Sample no. } & \alpha / \mathrm{mg} / \mathrm{hr} & \mathrm{Pb}(\mathrm{ppm}) & \text { Age (M.Y.) } \\ 106 & 152 & 5.8,5.6 & 90\end{array}$

CENPRAL ALASKA

\section{Birch Creek}

Geology

In 1949, White and Stevens (1953) in a reconnaissance investigation for radioactive minerals in the Ruby-Poorman district, west-central Alaska, collected samples of a disintegrated coarse-grained granite on Birch Creek, tributary to Flint Creek, Ruby quadrangle (fig. 5, sample no. 3469).

Mertie and Harrington (1924) describe three bodies of potash granite in the Ruby-Poorman district. One body of granite is on the east side of Sulatna River, northeast of Poorman; another is at the head of Flint Creek; the third lies along the ridge east of Birch Creek, a tributary of Flint Creek. They describe the granite from the three areas mentioned as a yellowish-gray holocrystalline, coarsely granular rock, locally porphyritic, with phenocrysts of orthoclase or microcline, and mica, with a subordinate amount of oligoclase or oligoclase-albite. 


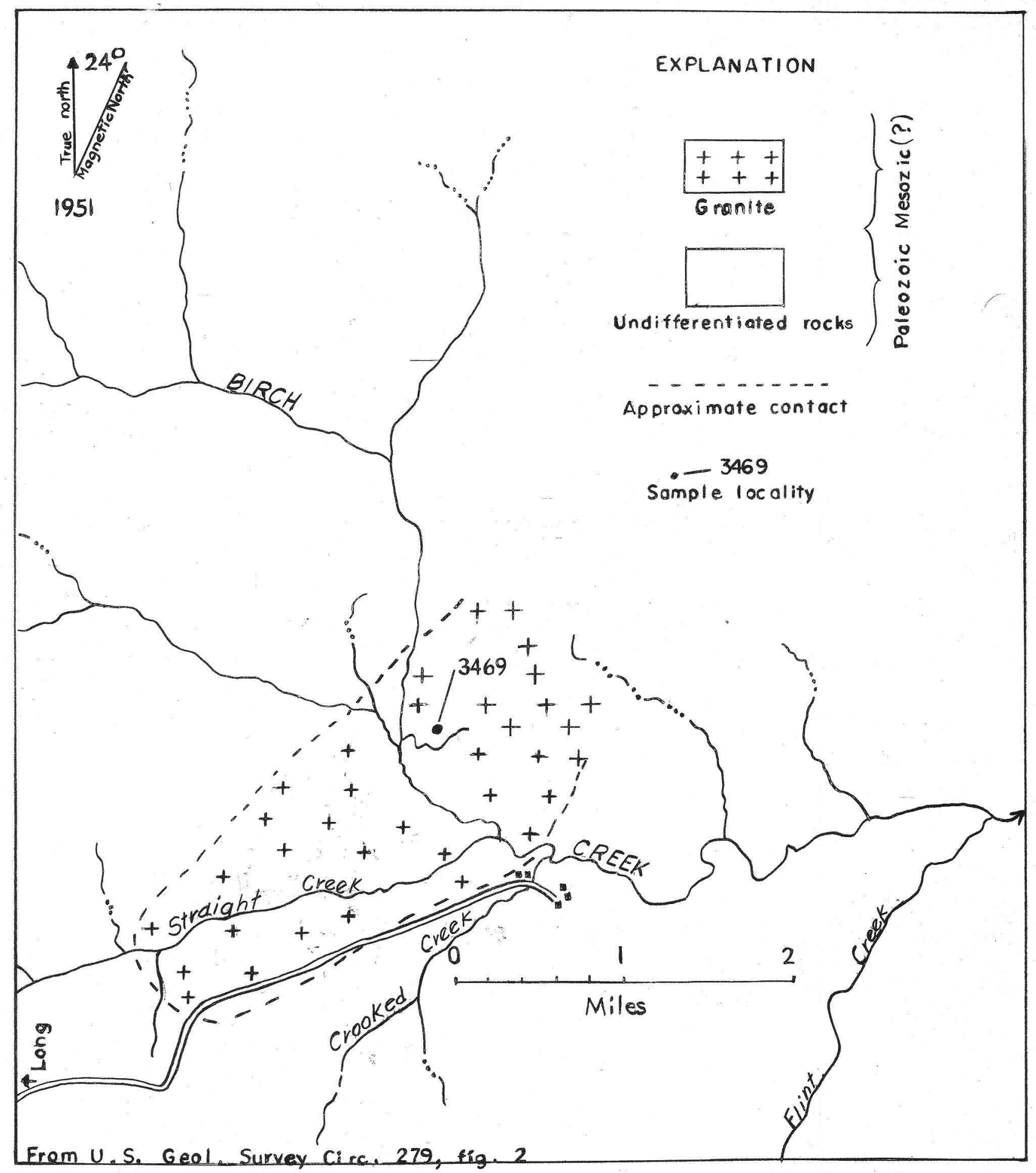

Figure 5:--Sketch map showing location of sample from Birch Creek, Ruby quadrangle, Alaska 
The granite on Birch Creek where sample 3469 was collected has been mapped by Mertie and Harrington (1924) and designated as Mesozoic by them principally on the basis of freshness and similarity to some of the granites in the Yukon-Tanana region. No stratigraphic evidence is available, however, that would indicate the exact age of the granite, and the field evidence indicates only that it is post-Mississippian.

\section{Age determination}

Age was determined on pale brown zircon, essentially fresh, with an omega ixdex of refraction of 1.92 and showing a slight amount of narrow optically continuous zoxing.

\begin{tabular}{cccc} 
Sample no. & $\alpha / \mathrm{mg} / \mathrm{hr}$ & Pb (ppm) & Age (M.Y.) \\
\hline $3469 \begin{array}{ccc}\text { (untreated) } \\
\text { (concentrated }\end{array}$ & 1342 & 30 & 54 \\
$\begin{array}{c}\text { nitric acid) } \\
\text { (concentrated } \\
\text { nitric acid) }\end{array}$ & 1366 & 29 & 53 \\
& & 26,27 & 47 \\
& Average age & 51 \\
& Flat Creek and Chicken Creek &
\end{tabular}

Geology

White and Killeen (1953) in 1947 made investigations for radioactive minerals in the vicinity of Flat, Iditarod quadrangle. Age determinations were made on zircons concentrated from two of their samples. They collected a sample (1895) of the quartz monzonite from near the head of Flat Creek, and a sample (1810) of the quartz monzonite at the head of Chicken Creek (fig. 6).

White and Killeen noted that the quartz monzonite at the headwaters of Flat and Chicken Creeks has two facies, a light-colored and 


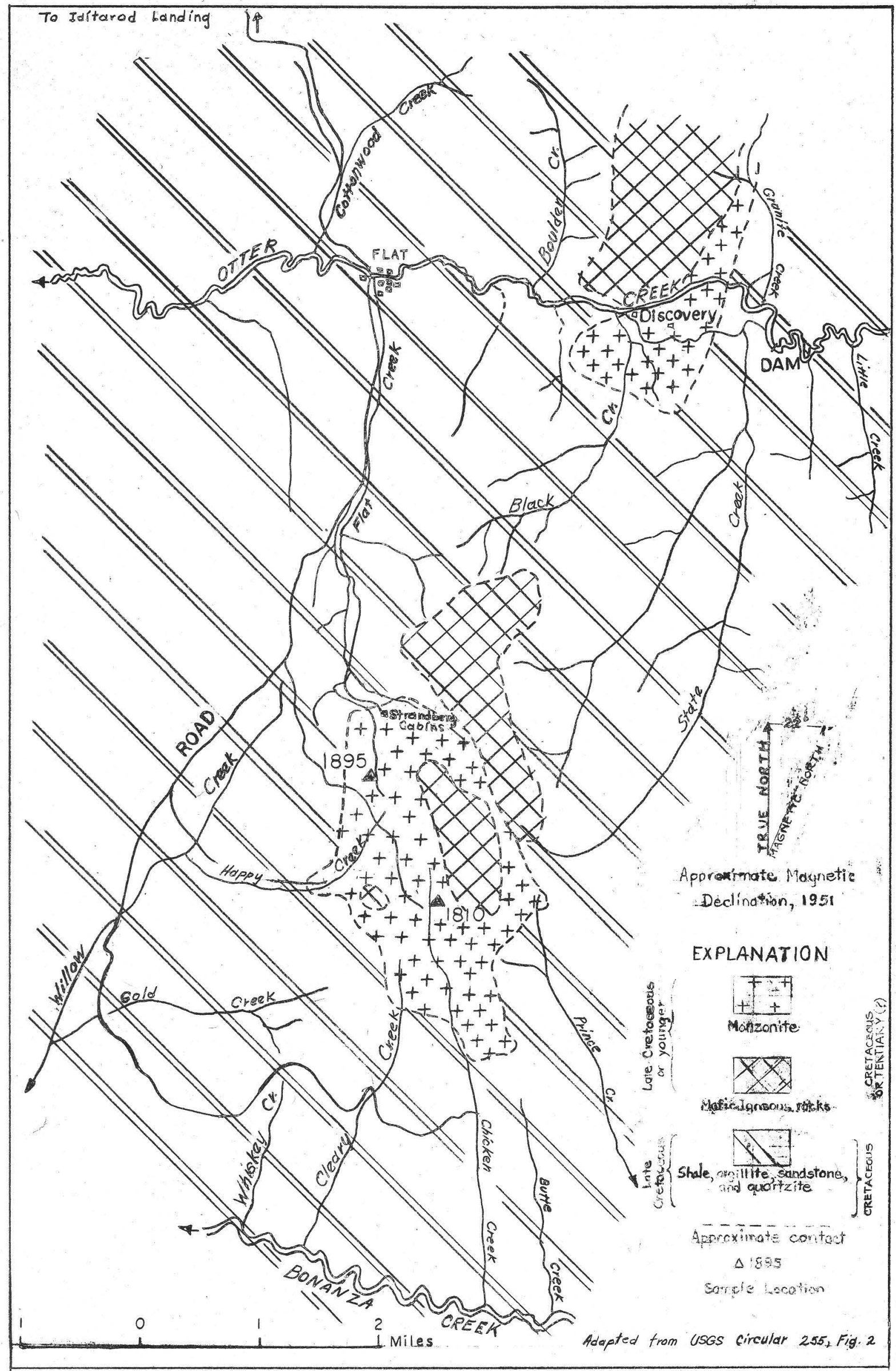

Figure 6.- Sketch map abowing 1ocations of samples from Flat Creak and 
a dark-colored facies, that do not appear to be gradational but show a distinct line of contact; the texture ranges from coarse- to fine-grained. Mertie and Harrington (1924, p. 70) described the quartz monzonite in the Flat area as composed essentially of orthoclase, plagioclase, quartz, augite, biotite, and hormblende, with minor amounts of magnetite, apatite and zircon. The plagioclase ranges from oligoclase to labradorite and is in amounts equal to that of the orthoclase. On the divide between the heads of Flat, Chicken, and Slate Creeks (fig. 6) the orthoclase and plagioclase are graphically intergrown. White and Killeen (1953, p. 8) noted that the biotite from the quartz monzonite in this area has numerous, very pronounced pleochroic halos, where it surrounds crystals of zircon and allanite(?).

The age of the quartz monzonite as determined from the field evidence is late Eocene or post-Eocene (Mertie and Harrington, 1924). The monzonite cuts sedimentary rocks of shale and sandstone of Late Cretaceous age; the monzonite is therefore post-Late Cretaceous.

Age determination

Age determination was made on fresh, clear, pale amber, doubly terminated zircon with index of refraction for omega of 1.92. No zoning was observed.

\begin{tabular}{cccc} 
Sample no. & $\mathrm{d} / \mathrm{mg} / \mathrm{hr}$ & $\mathrm{Pb}(\mathrm{ppm})$ & Age (M.Y.) \\
\hline 1895 & 334 & $6.2,7.0$ & 47 \\
1810 & 315 & $7.8,7.4$ & 58
\end{tabular}


Nixon Fork mines

Geology

Igneous rock from the Nixon Fork mining distriet, Medfra quadrangle, was collected in 1954 by J. J. Matzko and G. D. Eberlein for age determination studies. The sample (5044) was from the bedrock east of the Crystal Shaft mine (fig. 7).

Brown (1926, p. 124) describes the rock at Nixon Fork mines as a monzonite that contains orthoclase and plagioclase feldspar, quartz, brown biotite, green hormblende, and minor amounts of apatite, iron oxides, and pyroxene. A porphyry, closely related in composition to the monzonite, reportedly occurs as a chilled border phase of the monzonite body and as dikes.

A point count modal analysis of sample 5044, on which the age was determined, is shown below:

\begin{tabular}{lc} 
Perthite & 53 \\
Andesine & 33 \\
Hornblende, green & 11 \\
Others & 2 \\
Quartz & 1 \\
\cline { 2 - 2 } & 100
\end{tabular}

"Others" include biotite (dark brown and shows strong absorption), apatite, opaques, sphene, calcite, zircon and hematite. Sericite in minor amounts accompanies the plagioclase, and kaolin is more common with the perthite. The hornblende has altered partly to biotite and biotite has altered to chlorite. Some of the zircon embedded in the biotite shows pleochroic halos. Sphene is associated with the opaques and appears to be derived from them. 


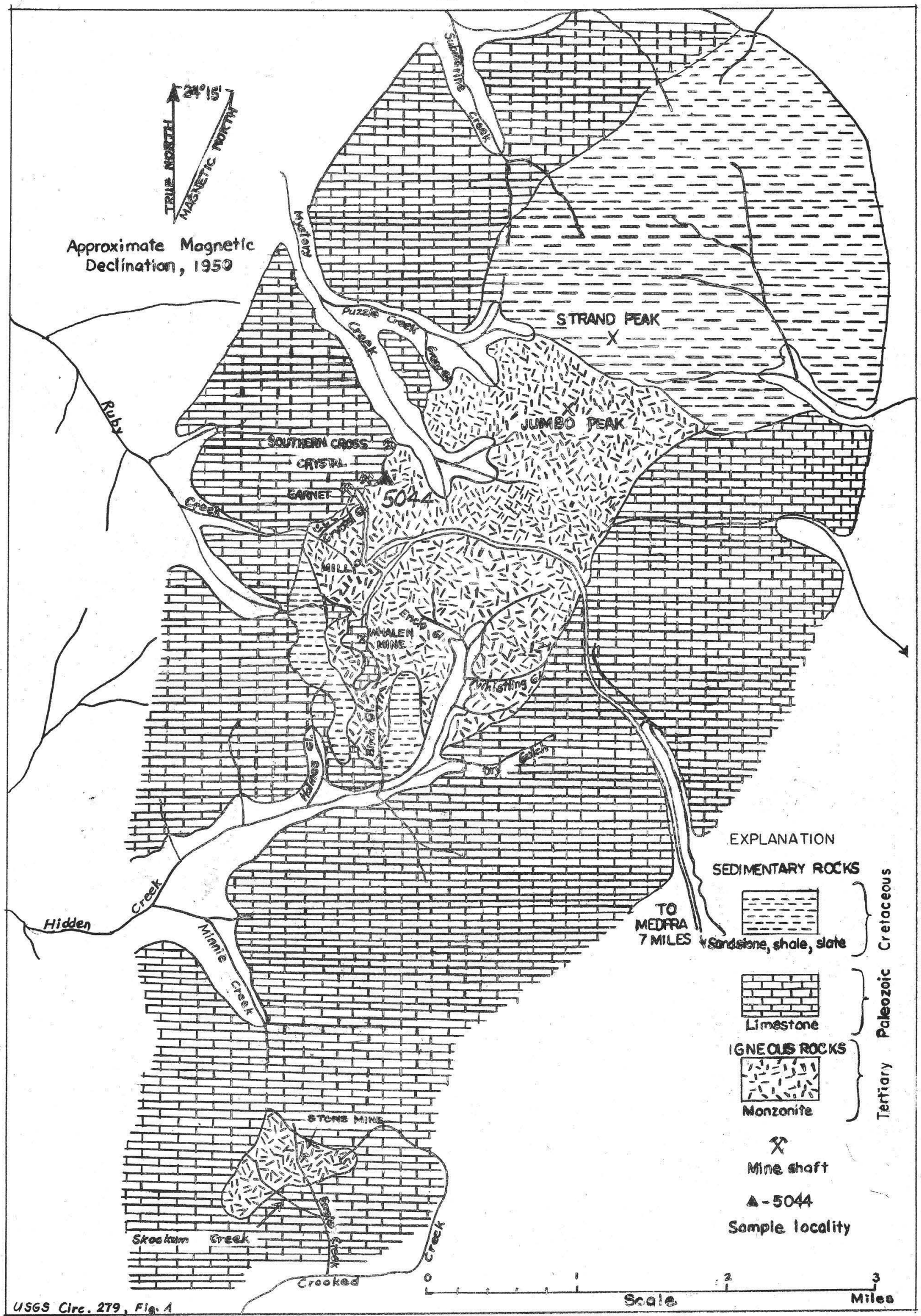

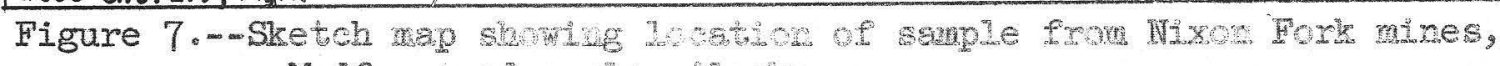


The average grain size is $1 \mathrm{~mm}$, but plagioclase laths show a maximum size of $3 \mathrm{~mm}$.

The age of the monzonite is believed by Brown (1926, p. 120) to be either Eocene or early Oligocene. In the Nixon Fork mines area that was sampled, the monzonite cuts limestone of Paleozoic age, and sandstone, shale, and slate of Late Cretaceous age.

\section{Age determination}

The zircons are similar to those from samples 1810 and 1895. They are fresh, clear, pale amber, doubly terminated, with no zoning detected, and have an index of refraction for omega of 1.92 .

\begin{tabular}{cccc} 
Sample no. & $\alpha / \mathrm{mg} / \mathrm{hr}$ & $\mathrm{Pb}(\mathrm{ppm})$ & Age (M.Y.) \\
\hline 5044 & 252 & $5.8,6.0$ & 56
\end{tabular}

\section{SUMMARY}

Lead-alpha age determinations on zircon from rocks of central Alaska gave an average age of 53 million years (table 1). This is compatible with an early Tertiary or Eocene and Paleocene ages undivided. The limits set by the Committee for the Measurement of Geologic Time (1949-50) are 1-60 million years for the Tertiary Period and 40-60 million years for the Eocene and Paleocene epochs undivided. Ages determined on three of the four rocks are in agreement with the geologic age assignment of very Late Cretaceous or early Tertiary (Brown, 1926, and Mertie and Harrington, 1924). The age determination of the other rock, from Birch Creek, Alaska, gave an early Tertiary age of 51 million years, in disagreement with the geologic age assignment of Mesozoic by Mertie and Harrington (1924). 
Ten age determinations on zircon from southeastern and east-central Alaska gave an average age of 96 million years, compatible with a Cretaceous assigmment; the limits for the Cretaceous Period are 60-130 million years according to the Cormittee on the Measurement of Geologic Time. Tentative assignments of geologic age to these rocks, made by Mertie (1937) and Buddington and Chapin (1929), are Late Jurassic or Early Cretaceous. In all probability, they are Cretaceous inasmuch as the average age of 96 million years is virtually the same as the average age of 100 million years determined on both zircon and monazite from four plutonic rocks, of early Late Cretaceous (post-Albian) age, from Baja California (Larsen, Gottfried, Jaffe, and Waring, manuscript in preparation). The lead-alpha age determinations of zircons from three of the early Late Cretaceous intrusives from Baja California were 95, 98, and 109 million years, respectively; monazite from an additional intrusive gave an age of 98 million years.

Table 1.-mSummary of lead-alpha age determinations of igneous rocks from Alasisa

Central Alaska

\begin{tabular}{|c|c|c|c|}
\hline Rocks & $\begin{array}{c}\text { Sample } \\
\text { no. }\end{array}$ & Area & $\operatorname{Age}\left(M_{0} Y_{0}\right)$ \\
\hline Granite & 3469 & Birch Creek(fig. 5) & $\begin{array}{l}53) \\
54) \\
47)\end{array}$ \\
\hline Quartz monzonite & 1895 & Flat Creek (fig. 6) & 47 \\
\hline Quartz monzonite & 1810 & Chicken Creek (fig. 6) & 58 \\
\hline Monzonite & 5044 & Nixon Fork Mines (fig. 7) & 56 \\
\hline \multicolumn{4}{|c|}{ 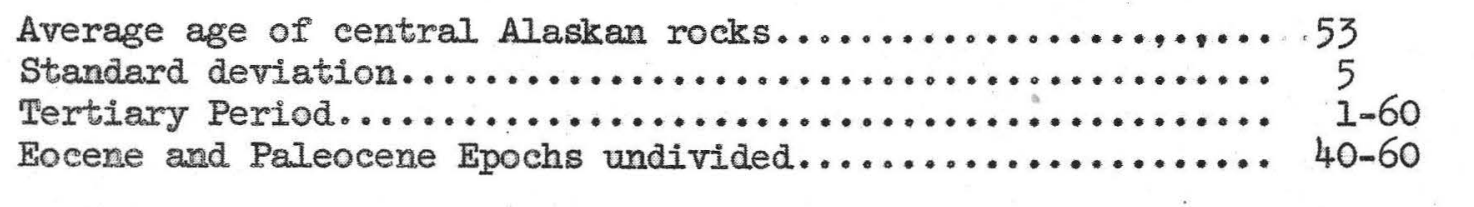 } \\
\hline
\end{tabular}


Table 1.--Surmary of lead-alpha age determinations of igneous rocks from Alasia--continued.

Southeastern and east-central Alaska

\begin{tabular}{|c|c|c|c|}
\hline \multicolumn{3}{|c|}{ Sample } & \multirow[b]{2}{*}{ Age (M.Y.) } \\
\hline Rocks & no. & Area & \\
\hline Leucosyenite & 3881 & Mt. Fairplay (fig. 2) & $\begin{array}{r}101) \\
95) \\
90) \\
102) \\
94) \\
106) \\
108) \\
96)\end{array}$ \\
\hline Granodiorite & 106 & Turner Lake(fig. 4) & 90 \\
\hline Quartz diorite & 242 & Tolstoi Point(fig. 3) & 100 \\
\hline \multicolumn{3}{|c|}{ 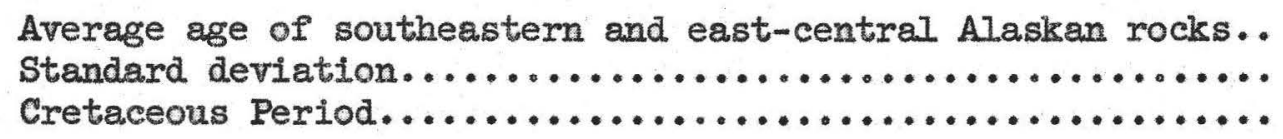 } & $\begin{array}{l}96 \\
6 \\
60-130\end{array}$ \\
\hline
\end{tabular}

REFERENCES CITED

Brown, J. S., 1926, The Nixon Fork country and silver-lead prospects near Ruby, Alaska: U. S. Geol. Survey Bull. 783-D, p. 97-150.

Buddington, A. F. and Chapin, Theodore, 1929, Geology and mineral deposits of southeastern Alaska: U. S. Geol. Survey Bull. 800, p. $1 \mathrm{~m}=398$.

Gottfried, David, Senftle, F. E., and Jaffe, H. W., 1955, Further evaluation of the Larsen method of age determination, (Abs.): Geol. Soc. America Bull. 66, p. 1565.

Jaffe, H. W., Gottfried, David, and Waring, C. I., 1955, Larsen-method age determinations of 150 rocks ranging in age from Precambrian through Tertiary (Abs.): Geol. Soc. America Bull. 66, p. 1580.

Larsen, E. S., Jr., Keevil, N. B., and Harrison, H. C., 1952, Method for determining the age of igneous rocks using the accessory minerals: Geol. Soc. America Bull. 63, p. 1045-1052.

Larsen, E. S., Jr., Gottfried, David, Jaffe, H. W., and Waring, C. I., (in preparation), Age determinations of zircon from rocks of the Southern California, Sierra Nevada, Idaho, and Coast Range batholiths. 


\section{(chairman)}

Marble, I. F./ 1950 , Summary Report of the Committee on the measurement of geologic time for 1949-1950: National Research Council, Division of Geology and Geography, Report of the Committee on the measurement of geologic time, 1949-1950, p.1-24: See pe 18 .

Mertie, J. B., Jr., and Harrington, G. L., 1924, The Ruby-Kuskokwim region, Alaska: U. S. Geol. Survey BuIl. 754, 129 p.

Mertie, J. B., Jr., 1937, The Yukon-Tanana region, Alaska: U. S. Geol. Survey Bull. 872, p. I-276.

Plafker, George (in preparation), Geologic investigations of proposed Sheep Creek, Carlson Creek, and Turner Lake power sites, Alaska: U. S. Geol. Survey Bull.

Sainsbury, C.I. (in preparation), Geology of the Craig C-2 quadrangle, southeastern Alaska: U. S. Geol. Survey Bull.

Warner, I. A., and Goddard, E. N. (In preparation), Geology and ore deposits of Kasaan Penirsula (Alaska): U. S. Geol. Survey BuIl.

White, Mas G., and Stevens, John M., 1.953, Reconnaissance for radioactive deposits in the Ruby-Poorman and Nixon Forik districts, west-central Alaska, 1949: U.S. Geol. Survey Cire. 279, p. I-9.

White, M. Go, and Killeer, P. I., 1953, Reconnaissance for radioactive deposits in the Lower Yukon-Kuskokwim Highlands region, Alaska, 1947: U. S. Geol. Survey Circ. 255, p. I-17.

Wright, Charles W., 1915, Geology and ore deposits of Copper Mountain and Kasaan Peninsula, Alaska: U. S. Geol. Survey Prof. Paper 87, p. $1=110$.

\section{UNPUBLISHED REPORTS}

White, Max G., Nelson, A. E., and Matzko, J. J., I956, Radiometric investigations along the Taylor Highway and part of the Tanana River, Alaska: U. S. Geol. Survey Trace Elements Memo. Rept. 329, $12 \mathrm{p}$.

Matzko, J. J., and Bates, R. G., (in preparation), Recomaissance for uranium and thorium in Alaska, 1954: U. S. Geol. Survey Trace Elements Inv。 Rept.611. 